\title{
Charactered Education in Learning Indonesian Language in the High School: Case Study in SMAN 1 Surakarta, Indonesia
}

\author{
Aulia Rahmanisa $^{1}$, Sarwiji Suwandi ${ }^{1}$, Slamet Subiyantoro ${ }^{1}$ \\ ${ }^{I}$ Postgraduate of Sebelas Maret University, Surakarta, Indonesia \\ auliarahmanisa@rocketmail.com
}

\begin{abstract}
Character education is the focus of Indonesian education nowadays as people in Indonesia is experiencing a negative character shifting. In order to change negative character, character education should be taught to the young generation through the integration of the character education at school. This study aims to determine the ways of integrating the value of character education in the lesson plan and the process of Indonesian language learning in the high school. This study employed a case study method by implementing a qualitative approach. This research was carried out in State Senior High School (SMAN) 1 Surakarta, Indonesia. The technique of data collection comprised of observation, interviews, and documentation. The result of this study shows that SMAN 1 Surakarta infuses character education in Indonesian language learning. The character values, which are integrated to the lesson plan, are respect, discipline, care, courage, responsibility, justice, honesty, helping each other, and cooperation. In the learning process, the character values that are infused to the lesson plan had been successfully integrated except for three values, namely justice, helping each other, and cooperation. Those three values should be integrated during group discussion activities, unfortunately, group discussion activities were not carried out.
\end{abstract}

Keywords: character education, Indonesian language learning, high school.

\section{Introduction}

Character education has become a national issue in Indonesian education nowadays. This is caused by many negative actions occurred because of the lack of national character. State officials who are representatives of many people were ensnared by corruption cases. In fact, in the beginning of September 2018 as many as 41 of the 45 members of Regional House of Representatives (DPRD) of Malang were named as suspects in corruption cases (Munir, 2018). Evidence from the low character of the nation is also shown in the high number of fraud cases that occurred in Indonesia. Norton, a cyber-security company states that in 2017 the total global losses due to fraud and online hacking reached IDR 4,419 trillion with victims reaching 987 million people. Some of them were 900 victims of fraud in the city of Solo with a loss of more than IDR 500 million, and online fraud in the city of Malang which resulted in a loss of IDR 2.5 billion (Suadi, 2018). Not only adults, teenagers also show the weak character of the nation. There were many cases of students getting pregnant out of wedlock. Data obtained from the Office of Population Control for Family Planning and Women's Empowerment (DPPKBPP) shows that during 2018 there were 1,059 cases of marriage at a young age and 64 percent of them occurred because these teenagers were pregnant (Julan, 2018). This is a very concerning consideration that these students should have a bright future with many achievements to advance the country, instead of quitting school due to pregnancy.

The government believes that to solve these character problems, we must begin to provide intensive character education at every level of education starting from elementary school, junior high school, and senior high school. The implementation of character education in schools can be pursued through three ways, namely the integration of character values into 
each subject, self-development activities, and school culture (Wibowo, 2012, p. 83). Of the three methods, integrating the value of character education in each subject is considered the most effective way. This is because students spend around eight hours a day participating in classroom learning. So, this is the most appropriate time to provide intensive character education.

However, the implementation of character education was not that easy as not all teachers were willing to take the time to integrate character education in classroom learning. Some teachers assumed that character education could interfere the effectiveness of the learning process. They revealed that character education should be the duty of parents, not teachers (Bohlin, 2005, p. 3). In fact, the character education in classroom learning does not take a lot of time. This is because the character education curriculum is a nurturing effect or a hidden curriculum, in other words the character values are implied in every field of study. In addition, character education has an impact on improving students' cognitive abilities. Lickona (2016, p. 149)states that character education can improve academic ability, because there will be a good relationship between the teachers and students and students with peers that will create an effective learning environment. In addition, character education will instill hard work habits that affect student education. According to research, Hokanson (2013, p. 107)shows that the strength of character or non-cognitive skills turns out to have more influence on one's career and future than his cognitive abilities. Based on the explanation above, it is clear that character education does not inhibit the effectiveness of cognitive learning, but rather supports the cognitive aspect itself.

Some teachers feel that they have carried out character education well, but in reality, there are students who do not have such characters. It is undeniable that globalization has influenced the way of thinking of young generation. They consider themselves as children of the millennium and it is really inappropriate to apply the value of outdated character (Saroni, 2013 , p. 23). It is obvious that a norm in society changes by time, but one must remember that not all old-fashioned things is bad, and vice versa, not all new thing is good. This is teacher's job as an educator to teach what is bad and what is good in accordance with the circumstances at the time (Purwanto, 2014, p. 28). However, back to the main problem, not all teachers carry out character education genuinely.

If we look closer, this happens because there is no assessment of the performance of teachers in carrying out character education. Nobody monitors whether the teacher has carried out character education or not. The only thing that is used as a measuring tool for the success of the teacher in carrying out character education is character shown by the students in the school.

The Indonesian Ministry of Education and Culture tries to assess the character of students through the assessment of schools with national level integrity. This assessment was done by measuring the level of integrity or honesty of students in the National Examination over the past five years (Basuki, 2018). The results of the assessment showed that from all schools in Indonesia, the city of Surakarta won the most awards. One of the schools that won the award was State Senior High School (SMAN) 1 Surakarta. This school was also the flagship school in the city.

Based on the explanation above, how SMAN 1 Surakarta integrates the character education in learning is an interesting topic to discuss. This research described how character valuesinfused in learning and what character values could be integrated. The results of this 
study were expected to be a reference for teachers in high schools to integrate character education in the teaching and learning process.

\section{Literature Review}

\subsection{Character Building}

The character (karakter in Indonesian) comes from Greek, karaso, which means blueprint, basic format, fingerprint. Pala (2011, p. 24) reveals that character is a characteristic or sign that distinguishes us from others. In a broader sense, Maksudin (2013, p. 3)states that character is a way of thinking and behaving that characterizes each individual to live and work together, both in the sphere of family, community, nation and state life. In line with this opinion, Samani (2011, p. 42) defines character as characteristics that shape and distinguish personal characteristics, ethical characteristics, and mental complexity from a person, group, or nation. So, it can be concluded that character is a person behavior and habits regarding his identity, way of thinking, and way of life, which distinguishes him from others.

Lickona (2016, p. 82) states that good character consists of knowing good things, wanting good things, and doing good things. To produce generations of good character, character education is needed. The method used to teach character according to Dewantara (1977, p. 484), a pioneer of education in Indonesia, is by using spontaneity method. Character teaching can be taught anytime spontaneously and embedded to other subject. Character education emphasizes the habits that are constantly practiced and done (Aqib \& Ahmad, 2017, p. 3). Therefore, teacher is required to have the ability to bring up the character values in daily learning process.

\subsection{Value in Character Education}

Lickona (2016, pp. 69-70) states that there are two main values that must be taught to students, namely respect and responsibility. Mutual respect, according to Zuriah (2015, p. 199)is attitudes and behaviors to respect the relationships between individuals and groups based on the norms and procedures that apply. Respect is divided into three, namely, respect for oneself, respect for others, and respect for all forms of life and the environment (Lickona, 2016, p. 70). Respect for yourself means that we must treat what is in our lives as human beings who have natural values. Unkind actions such as self-harm are prohibited. Respect for others means we must treat others as human beings who have high values and have the same rights as us as humans. Whereas respect for all forms of life and the environment, we must respect animals and plants and the earth we live in. Respect in this case means we do not harm animals and plants, and preserve the environment.

Responsibility is the ability to respond or answer. Responsibility is oriented towards other people, gives a form of attention, and actively responds to what they want. Responsibility also means carrying out a job or obligation wholeheartedly and giving the best (Lickona, 2016, pp. 72-73). The concrete form of a responsible attitude is able to do tasks properly, avoiding the attitude of blaming others, understanding and accepting risks or the consequences of an action on oneself and others (Zuriah, 2015, p. 98). In addition to these two main values, there are also supporting values that emerge along with the two main values, namely honesty, justice, tolerance, wisdom, self-discipline, help, caring for others, cooperation, courage, and democratic attitude. This overall value will be used as a reference in this study. 


\subsection{Character Education in Indonesian Language Learning}

Learning is an effort which is done by the teacher or others to teach students (Hasanah, 2012, p. 85). Indonesian language learning is in accordance with the current curriculum, is text-based learning. The text is a complete expression of the human mind in which there are situations and contexts. The text is not just the development of grammatical structures or a collection of sentences, but it is a realization of a value system, social norms, social processes with their social goals (Ramadiana, 2016, p. 225).

In order for Indonesian language learning to run optimally, the teacher must make a lesson plan. Lesson Plan is a guide in learning activities that include competencies that must be achieved, goals, materials, methods, models, media, and learning steps, as well as assessment instruments. Every teacher must make a lesson plan. The teacher must determine what character values will be integrated and what learning methods or models will be used to support the integration of these character values. After lessonplan is made in such a way, the next step is to carry out a learning process that integrates character values. However, a good lesson plan will not be useful if the teacher does not implement what he has planned in the lesson plan. The position of lesson plan is very important as guidance for teachers, but the learning process becomes the main thing because that is where students interact directly and feel the learning experience directly.

\section{Methods}

This research employed a case study research, which were a series of scientific activities carried out in depth to obtain knowledge of a case or event that occurred. The approach used in this study was a qualitative approach. Sugiyono (2012, p. 1)states that qualitative research is research used to examine objects naturally. Qualitative research is more concerned with the process than the results because the part studied will be more profound if observed in terms of the process.

The case examined in this study was how teachers integrated the value of character education in Indonesian language learning in high school. The school that was used as the location of the study was SMAN 1 Surakarta. This school was chosen because this school managed to get an award for school with national level integrity. This means that this school had succeeded in instilling character values in its students, namely the value of honesty, discipline, and responsibility. With precise school selection, it is expected that the results of this research can be used as examples of the implementation of character education in various high schools in the future.

The object in this study was the Indonesian Language subject teacher. Language learning was chosen because language was more laden with character values than other lessons. Various texts contained in language learning usually have a moral message that can be used as a means of character education. So, in addition to learning about the structure of the text, students also learned about character values. The main focus of the field of language studies was to prepare students to communicate well. When learning to communicate, students actually also learned about character values. These values could be found in the choice of words, sentences, language styles, dialects, and sentence songs. So that language contains a variety of values, such as the value of honesty, compliance, beauty, commitment, tolerance, independence, and togetherness (Maksudin, 2013, p. 87). 
This research was conducted in three ways i.e. document analysis, observation, and interviews. Document analysis was completed by analyzing lesson plan made by the teacher. Analyzed lesson plan was plan with material of Procedure Text. After analyzing the learning plan, the next step was to observe the learning process in the classroom. Observation was conducted to determine the alignment between the lesson plan and the implementation of plan and to find out the forms of integrating the value of character education that appeared in classroom learning. In order for this observation to run optimally, the researchers used tool in the form of a camera for recording. This media was very useful to minimize errors during data analysis. Interview was done to gather information about the efforts made by teachers in integrating the character value education in the classroom. Interview was conducted on two Indonesian Language teachers, one teacher from the observed class and one teacher from another class. In order for the results of the interview to be valid, interview was also conducted with two students from observed class.

To gather a valid data, triangulation was carried out. Triangulation is a technique of checking the validity of data that uses something else outside of the data for checking purposes or as a comparison to the data (Moleolong, 2000, p. 178). This study used data source triangulation i.e. data sourced from observation, interviews, and document analysis. The total participants involved in this study were 42 people, with details of 2 Indonesian Language teachers and 40 students. This research lasted for two months.

\section{Research Results and Discussion}

The implementation of character education in SMAN 1 Surakarta was integrated into every subject, including Indonesian language. The value of character education had been integrated starting from lesson plan, learning process in the classroom, and assessment. Lesson plan analyzed in this study was lesson plan of Procedure Text. Character values appeared in lesson plan (RPP) were in forms of implicit and explicit. Explicitly, this value appeared in the step of learning activities, such as respect, discipline, caring, courage, and responsibility. Whereas in the implicit form, the five previous valuesinfused to the learning were justice, honesty, help each other and cooperation. The character value of respect was the value that most often appeared. Since the beginning of learning, students had been designed to have the character of respect through greetings. These activities can be seen in the following quote:

Students answer greetings and then answer to teacher in checking attendance, then students respond to questions related to previous conditions and learning (RPP-01)

Greetings by teachers to students and vice versa were forms of respect for others. No matter whether the person was older or younger, students were taught to respect everyone. The character value of respect did not only appear in greetings, but also in presentation activities. This is shown in the following quote:

Students present, respond, and revise the procedure text. Other groups respond responsively and politely. (RPP-02)

Courteous means smooth and good. Students were asked to always speak responsively and politely. This means that students must be able to convey their intentions without hurting others. This is an example of respectful character values instilment.

The next character value is discipline. This character value appeared when the teachers checked student attendance. Students must be disciplined, present and punctual. This 
attendance activity was in the preliminary step, the goal was that the teachers knew the students who were late and absent. So, teachers could reprimand the student at the next meeting.

The caring character value appeared when the teacher gave an explanation. Caring means paying attention. Students were expected to be able to pay attention to the teacher's explanation carefully, not to make a fuss so that students could understand the material properly. If students had been able to instill a caring attitude during learning, it was expected that students could also apply the caring character in their daily lives. The caring character shows in the following quote:

To build the learning context, with caring and polite attitude students observe the explanation of the teacher related to the learning material. (RPP-03)

The value of the character of courage arose from a confident attitude that was expected by the teacher to be shown by students when presenting the results of their discussion. This can be seen in the following quote.

Students present the meaning / purpose of the procedure text with confidence. (RPP-04)

The character value of the responsibility was integrated in the closing activity, which was when making conclusions. The activity of concluding learning required the character of responsibility because when summing up the lesson, it meant that students accounted for the tasks that had been given to them, namely understanding the material that had been taught and discussed. The character value of responsibility can be seen in the following quote:

With an attitude of responsibility, care, responsiveness, and politeness, students and teachers conclude learning. (RPP-05)

In addition to the character values expressed in the steps of the learning activities above, there were character values implied in the learning method used. This learning used group discussion methods. In discussion activity, teachers had integrated several character values, namely justice, responsibility, honesty, caring for others, helping, courage, respect, cooperation, and discipline. Before conducting group discussions, the teacher must divide students into several groups fairly. After that, the teacher assigned assignments to each group. The task of the group leader was to share tasks with each group member fairly. All group members were responsible for completing their tasks properly. This task must be done honestly by the results of one's own thoughts, not cheating on friends or copying from the Internet. If there is a friend of a group who had difficulty, then the other students must show their care by helping the friend. Then, if all group members had completed their respective tasks, then each group member presents their work to their group friends so all members will understand the material. If there ware differences of opinion, then students must have the courage to express their opinions. However they should not be selfish and still have to respect friends' opinions. This activity was a form of group cooperation so that learning objectives could be achieved. All of the group's assignments must be completed right at the appointed time. This means that students must do this task with discipline. All character values integrated in the lesson plan can be seen in the following table. 
Table 1: Integration of Character EducationValues in Lesson Plan

\begin{tabular}{|l|l|}
\hline \multicolumn{1}{|c|}{ Character Value } & \multicolumn{1}{c|}{ Activity } \\
\hline Respect & $\begin{array}{l}\text { - Greetings before starting learning activities and after learning } \\
\text { activities begin. }\end{array}$ \\
& $\begin{array}{l}\text { Listen to the teacher explaining the learning material. } \\
- \text { Respect the opinions of friends. }\end{array}$ \\
\hline Discipline & $\begin{array}{l}\text { - Present on time. } \\
- \text { Able to complete assignments on time. }\end{array}$ \\
\hline Caring & Students must listen to the teacher's explanation carefully. \\
\hline Courage & Able to express opinions in discussions. \\
\hline Responsibility & Able to complete the tasks given by the teacher. \\
\hline Justice & $\begin{array}{l}\text { The teacher divides the group fairly. } \\
- \text { The group leader divides tasks for each group member evenly. }\end{array}$ \\
\hline Honest & Completing assignments with own abilities, not cheating. \\
\hline Help Each Other & $\begin{array}{l}\text { Students help a group of friends who have difficulty completing } \\
\text { assignments. }\end{array}$ \\
\hline Cooperative & $\begin{array}{l}\text { All group members work together to complete the task given by the } \\
\text { teacher. }\end{array}$ \\
\hline
\end{tabular}

Unlike the lesson plan, the process of learning the procedure text in the classroomused different method. In lesson plan, the teacher planned learning with group discussion methods, while in the application the teacher used the lecture method. According to the teacher (GR), she did not have enough time to carry out group discussions. In order to be more effective, teachers chose to do one-way learning (teacher-centered) rather than carrying out independent learning (student-centered) through group discussion activities. This method had to be done so that students understood better the material being taught. In the teacher interview activity stated:

"The lecture method cannot actually be eliminated, because if we only give a brief assignment and explanation, the child will have difficulty understanding the material". (GR-01)

The teacher believes that all learning methods used can integrate the value of character education, including the lecture method. The following statement supports this statement:

"Actually this character education can be included in any method. These Indonesian teachers usually speak in class more often, but even so, when the teacher speaks the value of the character is already in it. For example, when the teacher speaks, students can learn discipline and respect others by listening carefully to what the teacher is saying. "(GR-02)

In accordance with the teacher's statement above, the results of the observation indicated that the teacher had integrated the value of character education in the learning process in the classroom. Character values integrated were respect, responsibility, discipline, courage, honesty, and caring. Just like the draft in the lesson plan, the value of the character of respect was integrated through greetings. The teacher always greeted students before and after learning activities. If this was done continuously, it would shape students' respect. Besides greetings, respect was also integrated when students listened to the teacher's 
explanation. Students should not be noisy when the teacher was speaking. This certainly taught students to always respect others.

The character values of discipline was integrated during students' attendance checking activities, assignments, and giving advice by the teacher. Teacher always checked the attendance list at the beginning of learning to find out students who were late or not attending classes. This attendance activity was useful so that students realized that attendance was very important, so students could not be late or skipped school. Discipline was essentially able to manage time in accordance with the objectives to be achieved. When given an assignment, students must be able to manage time so that the task could be submitted on time. In addition to discipline in carrying out tasks, the value of the character of the discipline was integrated when the teacher advised his students to always manage time. Teacher advised students to be able to share time between school, extracurricular activities, and family activity at home.

The character value of responsibility arose when students were given assignments. Students must be responsible for completing the assignments that had been given. The form of responsibility also arose when the teacher gave answer choices, then the student chose the answer, then the student was responsible for the choice. He must be able to express the reason why he chose the answer, and if he was wrong then he must be willing to not get score.

The value of the character of courage appeared when students answered questions, both direct questions and wrote answers in the board. In the learning process, teachers gave direct questions to students. Then, students who had the courage would immediately raise their hands and answered the question. This student would eventually influence other students to be brave. In the next question, there would be other students raised their hands too.

The integration of caring character was when students listened to the teacher's explanation. Caring means ignoring or paying close attention. Students were taught to pay attention to the teacher explanation so that the information conveyed could be understood properly. In addition, the value of caring characters was also integrated when the teacher gave advice to his students. The teacher showed care by prohibiting students from eating carelessly and telling students to live a healthy life. The caring attitude shown by the teacher could be an example for students.

Honest character value was integrated in every assignment given. Students must do the work honestly with their own thoughts. Students were not allowed to cheat or did plagiarism from the Internet. The lecture method made it easy for the teacher to supervise students so that they were always honest because they did all the tasks by themselves. All integrated character values in the learning process can be seen in the following table.

Table 2: Integrating the Value of Character Education in the Learning Process

\begin{tabular}{|l|l|}
\hline \multicolumn{1}{|c|}{ Character Value } & \multicolumn{1}{|c|}{ Activity } \\
\hline Respect & - Pronunciation before learning activities and after learning \\
& activities has begun. \\
& - Listen to teachers explaining disciplinary learning material \\
\hline Discipline & - Present on time. \\
& - Able to complete assignments on time. \\
& - Able to manage time between learning and activities. \\
\hline Responsible & - Able to complete tasks given by the teacher. \\
& - Able to give reason for the selected answer \\
\hline
\end{tabular}




\begin{tabular}{|l|l|}
\hline Courage & $\begin{array}{l}\text { Dare to present in front of the class without being appointed by } \\
\text { the teacher. }\end{array}$ \\
& - Dare to raise hand to answer the teacher's question. \\
\hline Caring & $-\begin{array}{l}\text { Students must listen to the teacher's explanation carefully. } \\
-\end{array}$ \\
\hline Honesty & $\begin{array}{l}\text { Students must complete the task with their own abilities they } \\
\text { should not cheat. }\end{array}$ \\
\hline
\end{tabular}

Based on the results of the analysis of the documents and the learning process, it can be seen that there is a reduction in the integrated character values in learning. This is because the teacher did not carry out the discussion method as planned in the lesson plan. The character values of justice, help, and cooperation did not appear in learning activities because these three values were planned to be integrated in group discussion activities. This was very unfortunate, because through group activities students could learn more character values. Through interviews, students (SW) expressed their disappointment with the learning methods applied by the teacher.

"Actually in 2013 curriculum teachers present problems, then students discuss to solve the problem, but this teacher did not do that and used conventional teaching method." (SW-01)

"I hope that in the future this character education will be intensified through more active learning." (SW-01)

The students did not seem to realize that even though they did not carry out group activities, teachers had succeeded in integrating six values of character education. This was natural because teacherstred to instill implicit character values in every step of learning. Without realizing it students had obtained character education. Other students who were taught also stated that the method used by the teacher in teaching character education was in accordance with his expectation.

"I think that character education should be taught implicitly every day, for example in learning." (SW-02)

"If it can be integrated into learning implicitly, then it will not be disturbing, just like a normal teaching learning process. However, if taught explicitly, for example 'Budi reads diligently. Love to read is the value of the character that we have to teach 'and so on, we will feel patronized and it is disturbing. "(SW-02)

In order for the learning process to take place comfortably and effectively, the teacher should involve students in the preparation of learning plans. So, teachers can find out what learning methods students want. This is important because if students do not feel comfortable with the learning process that takes place, then students will also find it difficult to absorb all the knowledge taught, including the value of character education itself.

From scoring system, character assessment appeared in lesson plan in the form of an attitude assessment sheet. Character values that were used as assessment indicators in basic competency of Procedures Text were discipline, honesty, responsibility, respect, and cooperation. The cooperation value itself appeared with the details, "Collaboration in discussion." This means that the teacher expected this value to be integrated in discussion activities. The value that had been given by Indonesian language subject teachers occurred during the learning process. 
"The value, at the end of the semester, would be collected to the homeroom teacher to be processed and included in the report card. So for example 9 out of 13 teachers gave less value, and the rest give quite value, then it would be taken into consideration by the homeroom teacher to determine its value. In addition, the homeroom teacher also gets consideration from the teacher of civics education, religion, and school counselor"'(GR-02)

Of course the attitude assessment included in the teacher report could not describe the overall character of students. The success of new character education was seen from the way students live their lives, whether it is in accordance with the norms prevailing in the community or not.

\section{Conclusion}

Based on the research above, it can be concluded that the value of character education had been integrated in the Indonesian language learning in SMAN 1 Surakarta. Lesson plan of Procedure Text integrated the value of the character of respect, discipline, caring, courage, responsibility, justice, honesty, helping each others, and cooperation. These values were infused in the steps of teaching and learning activities. However, in its application in class, the value of justice, help each other, and cooperation had not been integrated. This was because those three values were planned to be instilled in group discussion activities, but in reality these activities were not carried out. Teachers should carry out learning in accordance with the lesson plans, so that there is no reduced character value in the learning process. In addition, the teacher can involve students to develop learning plans, in the sense of listening to students' aspirations about what they want to learn. Another way of teachers to integrate the value of character education in daily learning activities were to carry out group activities to improve social character. Besides, it also provides advice that can improve students' positive character in the teaching and learning activities, and utilize supporting media and teaching materials that contains more character values or contains character values, which were not written on student handbooks so that character education could run optimally.

\section{References}

Aqib, Z., \& Ahmad, A. (2017). Pedoman Pendidikan Budaya dan Karakter Bangsa. Yogyakarta: Gava Media.

Basuki, M. (2018). Sekolah Solo Raih Penghargaan UN Berintegritas. Retrieved from https://news.okezone.com/read/2015/12/17/65/1269764/15-sekolah-solo-raihpenghargaan-un-berintegritas

Bohlin, K. (2005). Teaching Character Education Through Literature. New York: Routledge Falmer.

Dewantara, K. H. (1977). Pendidikan. Yogyakarta: Majelis Luhur Persatuan Taman Siswa.

Hasanah, A. (2012). Pengembangan Profesi Keguruan. Bandung: Pustaka Setia.

Hokanson, B., \& Roger, W. K. (2013). Borderlands: Developing Character Strengths for a Knowmadic World. On The Horizon21(2), 107-113.

Julan. (2018). Kasus Pelajar Hamil Makin Marak. Retrieved from https://daerah.sindonews.com/read/1318786/23/duh-kasus-pelajar-hamil-makinmarak-1530691817 
Lickona, T. (2016). Mendidik Untuk Membentuk Karakter: Bagaimana Sekolah Dapat Memberikan Pendidikan Tentang Sikap Hormat dan Bertanggung Jawab. Jakarta: Bumi Aksara.

Lickona, T. (2016). Persoalan Karakter: Bagaimana Membantu Anak Mengembangkan Penilaian yang Baik, Integritas, dan Kebijakan Penting Lainnya. Jakarta: Bumi Aksara.

Maksudin. (2013). Pendidikan Karakter Non-Dikotomik. Yogyakarta: Pustaka Pelajar.

Moleolong, L. J. (2000). Metodologi Penelitian Kualitatif. Bandung: Remaja Rosdakarya.

Munir. (2018). Aggota DPRD Malang Tersangka Begini Pesan Mendagri untuk Parpol. Retrieved from https://nasional.sindonews.com/read/1335808/13/41-anggota-dprdmalang-tersangka-begini-pesan-mendagri-untuk-parpol-1536128264

Pala, A. (2011). The Need for Character Education. International Journal of Social Sciences and Humanity Studies 3(2), 23-32.

Purwanto, M. N. (2014). Ilmu Pendidikan Teoretis dan Praktis. Bandung: Remaja Rosdakarya.

Ramadiana, F. (2016). Konsep Bahasa Berbasis teks pada Buku Ajar Kurikulum 2013. Stilistika: Jurnal Bahasa, Sastra dan Pengajarannya 1(2), 224-236.

Samani, M., \& Hariyanto. (2011). Konsep dan Model Pendidikan Karakter. Bandung: Remaja Rosdakarya.

Saroni, M. (2013). Best Practice: Langkah Efektif Meningkatkan Kualitas Karakter Warga Sekolah. Yogyakarta: Az Ruzz Media.

Suadi. (2018). Korban Penipuan Online Indonesia Tertinggi di Dunia. Retrieved from http://www.medanbisnisdaily.com/news/read/2018/03/22/341459/korban-penipuanonline-indonesia-tertinggi-di-dunia

Sugiyono. (2012). Memahami Penelitian Kualitatif. Bandung: Alfabeta.

Wibowo, A. (2012). Pendidikan Karakter: Strategi Membangun Karakter Bangsa Berperadaban. Yogyakarta: Pustaka Pelajar.

Zuriah, N. (2015). Pendidikan Moral dan Budi Pekerti dalam Perspektif Perubahan: Menggagas Platform Pendidikan Budi Pekerti secara Kontekstual dan Futuristik. Jakarta: Bumi Aksara. 